\title{
Penerapan Pendekatan Konseling Eksistensial Humanistik untuk Mengurangi Perilaku Hedonis Siswa di SMAN 10 Makassar
}

\author{
Qawiyyan Fitri, Alimuddin Mahmud, Abdul Saman \\ Fakultas Ilmu Pendidikan, Universitas Negeri Makassar, Indonesia \\ e-mail: qawiyyanf30@gmail.com
}

\begin{abstract}
This study aims to examine the effectiveness of counseling with existential humanistic approach to reduce students' hedonic behavior. This study used Pre-Experimental Design with One-Group Pretest-Posttest Designs. Data was collected using questionnaire and observation instruments. Data analysis used descriptive statistical analysis and non parametric inferential statistical analysis. The results of research showed that the hedonist behavior of the students before being given the treatment was in the high category and after being given the treatment of humanistic existential counseling is in the low category. The treatment was be given through three steps namely preliminary step, mid step and termination step with seven times for face-to-face meetings.
\end{abstract}

Keywords: counseling, existential, humanistic, hedonist, student

\begin{abstract}
Abstrak
Penelitian ini bertujuan untuk menguji efektivitas dari penerapan pendekatan konseling eksistensial humanistik dalam mengurangi perilaku hedonis siswa. Metode penelitian menggunakan Pre-Experimental Designs dengan rancangan One-Group Pretest-Posttest Design. Pengumpulan data menggunakan instrumen kuesioner dan observasi. Data dianalisis menggunakan analisis statistik deskriptif dan analisis statistik inferensial non parametrik. Hasil penelitian menunjukkan bahwa perilaku hedonis siswa sebelum diberikan perlakuan berada pada kategori tinggi dan setelah diberi perlakuan pendekatan konseling eksistensial humanistik berada pada kategori rendah. Pemberian perlakuan melalui tiga tahap yakni tahap pendahuluan, tahap pertengahan dan tahap pengakhiran dengan tujuh kali pertemuan tatap muka.
\end{abstract}

Kata Kunci: konseling, eksistensial, humanistik, hedonis, siswa

\section{Pendahuluan}

Era modernisasi merupakan satu tanda perkembangan globalisasi yang mampu membuat perilaku remaja menjadi hedonis. Hedonisme adalah pandangan hidup atau paham individu yang keseluruhan aktivitasnya merupakan hal-hal yang berkaitan dengan kesenangan semata sehingga hal itu adalah sebuah hal yang mutlak ada di dalam kehidupan, kenikmatan atau menghindari perasaan-perasaan tidak enak, sehingga individu yang menganut paham ini dijalankan dengan sebebas-bebasnya demi memenuhi keinginannya (Pontania, 2016).
Hedonisme remaja saat ini merupakan hal yang menunjukkan bahwa semua hal di dunia ini patut untuk dicoba meskipun hanya sekali. Fenomena perilaku hedonis remaja ini yang sangat dipengaruhi oleh gaya hidup yang selalu ingin terlihat menawan, memakai brand yang mudah dilihat oleh orang lain agar menarik perhatian dan diakui (Nitadyah, 2015). Gaya hidup hedonisme saat ini memang terjadi pada semua lapisan generasi tanpa kecuali, terutama dalam hal ini banyak ditemukan pada remaja (Gemilang \& Christiana, 2016).

Siswa Sekolah Menengah Atas merupakan golongan yang memasuki masa remaja yang identik dengan fase yang 
senang mencoba (Santrock dalam Nadzir \& Ingarianti, 2015). Perubahan dunia yang berlangsung sangat cepat mengakibatkan perubahan secara khusus untuk siswa-siswi SMA, baik itu yang menyangkut perubahan perilaku, sikap, maupun pengalaman mereka.

Saat ini orang kurang banyak dihadapkan pada apa yang "harus" mereka lakukan (Santre dalam Jones, 2011). Pada situasi pengambilan keputusan dalam kehidupan nyata, kita sering dihadapkan dengan alternatif yang tampak sangat setara sehingga pilihan itu sangat sulit (Craik, Rose, \& Gopie, 2015, p. 1271). Upaya untuk menghilangkan pikiran dan perasaan yang tidak diinginkan biasa-nya menghasilkan "perang internal dalam diri" antara apa yang dirasakan individu dan cara yang diinginkannya. Perang internal ini sering menandai perpecahan antara yang mengalami dan diri kritis (Greenberg dalam Wolfe, 2016). Alih-alih, penekanannya adalah pada apa yang ingin mereka lakukan, dalam periode transisional antara ways of being lama dan baru di dunia, banyak yang gagal untuk belajar secara akurat bagaimana berkeinginan, bagaimana berkemauan, dan bagaimana memutuskan dan tetap pada keputusannya. Eksistensi remaja hanya dihargai sebatas kepemilikan dan status semata (Pontania, 2016).

Susianto (dalam Trimartani, 2014) menjelaskan bahwa gambaran perilaku hedonis memiliki ciri-ciri, yaitu segala aktivitasnya mengarah kepada hal-hal yang menurutnya nyaman, senang dengan semua hal yang berada di luar rumah, memilihmilih teman dan membuat relasi yang sesuai keinginannya, senang menjadi pusat perhatian, waktu yang dihabiskan hanyalah untuk bersenang-senang serta biasanya mereka berasal dari keluarga yang mampu secara ekonomi. Sehingga apabila dibiarkan, akan membuat siswa rapuh terhadap tantangan, tidak bertanggung jawab, dan memengaruhi prestasi akademiknya yang akan berakibat buruk terhadap pencapaian cita-citanya.
Nitadyah (2015) memaparkan bahwa secara umum hedonisme memandang bahwa tidak ada hal yang lebih baik dan lebih bermanfaat dibandingkan melakukan hal-hal yang disenangi dan terhindar dari segala hal yang membebankan. Perasaanperasaan tersebut akan membawa kepuasan tersendiri bagi diri meskipun hal tersebut bisa saja bertentangan dengan nilai budaya, agama, dan moral yang ada di masyarakat.

Kotler dan Amstrong (dalam Sarlina, 2016) menyatakan bahwa terdapat beberapa faktor yang bisa memengaruhi gaya hedonis. Faktor internal diantaranya konsep diri, sikap, persepsi, pengamatan dan pengalaman, motif, serta kepribadian. Adapun faktor eksternal meliputi kelompok yang dijadikan panutan, kelas sosial, kebudayaan, dan keluarga. Menurut Well dan Tigert (dalam Nadzir \& Ingarianti, 2015), terdapat 3 aspek dalam gaya hidup hedonis yaitu: aktivitas, minat, dan opini.

Remaja lebih senang melakukan halhal yang sifatnya non produktif, eksistensi remaja saat ini dapat diwujudkan dengan memakai pakaian serta aksesori dari merek ternama, berjalan-jalan ke mall, maupun menggunakan smartphone paling baru, eksistensi mereka dihargai hanya karena label yang mereka pakai (Pontania, 2016).

Kegiatan yang dilakukan siswa-siswa tersebut tidak ada yang berhubungan dengan tanggung jawabnya sebagai seorang pelajar, akibatnya adalah siswa tersebut tidak mengerjakan tugas yang diberikan, tidak memerhatikan penjelasan guru saat proses belajar mengajar berlangsung, tidak ada waktu untuk belajar, dan bahkan tidak lagi memerhatikan pendidikannya. Maka dari itu diperlukan layanan bimbingan konseling agar siswa dapat menata diri sebagaimana mestinya, sebagai seorang siswa dan seorang remaja. Apabila kecenderungan ini tidak segera diatasi dan sampai melebihi batas akan membuat mereka terperangkap dalam hal-hal yang tidak produktif dan bahkan keluar dari norma-norma moral. Sehingga peneliti memandang bahwa mereka harus segera 
diberikan tindakan treatment berupa konseling.

Konseling merupakan suatu proses pemberian bantuan yang dilakukan konselor kepada klien untuk dapat mengatasi permasalahan yang ada pada diri klien (Yulianto, 2015). Tujuan konseling untuk menghapus pola tingkah laku maladaptif, mempelajari pola tingkah laku konstruktif, dan mengubah tingkah laku (Corey dalam Lubis, 2011).

Konseling eksistensial humanistik bertujuan agar klien mengalami keberadaannya secara otentik dengan menjadi sadar atas keberadaan dan potensipotensi serta sadar bahwa ia dapat membuka diri dan bertindak sesuai kemampuannya (Primayanti, Madriantari, \& Dantes, 2014). Kata eksistensi diambil dari kata Latin existere, yang secara harfiah berarti "menonjol atau timbul". Eksistensi bukan proses statistik, tetapi melibatkan proses coming into being atau becoming (menjadi). Humanistik adalah suatu teori yang tertuju pada masalah bagaimana tiap individu dipengaruhi dan dibimbing oleh maksud-maksud pribadi yang mereka hubungkan kepada pengalaman-pengalaman mereka sendiri (Rochem, 2011). Wijaya (2014) mengemukakan bahwa pendekatan eksistensial humanistik memiliki pengaruh yang besar dalam memahami keberadaan (eksistensi) diri individu dan sadar akan potensi dirinya serta mampu membangun tanggung jawab dalam kehidupannya.

Corey (dalam Sabrina, 2016) menyatakan bahwa konseling eksistensial humanistik berfokus pada perkembangan kehidupan yang positif. Konseling eksistensial humanistik memiliki konsep yang mengarah pada kehidupan sekarang yang akan sangat berpengaruh pada masa depan seseorang, berdasarkan perilaku sekarang yang bisa menentukan nasib masa depannya. Konseling eksistensial humanistik membuat kondisi-kondisi dalam memaksimalkan kesadaran diri guna menghapus penghambat dalam mengoptimalkan potensi, dan memilih jalan untuk mencapai kebebasan yang harus diikuti oleh tanggung jawab secara sadar.

Eksistensial humanistik membuka jalan untuk mengalami dan melihat keterkaitan dari hal-hal yang sudah ada, bahkan ide-ide yang pada akhirnya disatukan dalam upaya mereka yang berfokus pada hati untuk mengurangi penderitaan yang tidak perlu dan memperluas kapasitas manusia untuk kesadaran, pertumbuhan, dan kehidupan yang bermakna (Felder, Aten, Neudeck, Shiomi-Chen, \& Robbins, 2014). Secara lebih spesifik, konseling eksistensial huma-nistik membantu klien untuk memulai perjalanan investigasi dirinya, dengan tujuan: memahami konflik tak sadarnya; mengidentifikasi mekanisme pertahanan diri yang salah; menemukan pengaruh; mengurangi tingkat kecemasan berlebihan dalam bermasyarakat; mengembangkan cara untuk mengatasi kecemasan yang berasal dari pikiranpikiran individu (May \& Yalom, 2005; Jones, 2011).

Pendekatan eksistensial humanistik tidak memiliki teknik khusus dalam pelaksanaannya. Perspektif teknik eksistensial dipandang sebagai alternatif yang membuat individu sadar akan tanggung jawabnya dalam menjalani kehidupan. Bagian ini berbicara tentang implikasi konseling dari gagasan yang telah dikembangkan di muka, yang meliputi kapasitas untuk sadar akan dirinya, kebebasan dan tanggung jawab, usaha untuk mendapatkan identitas dan bisa berhubungan dengan orang lain, pencarian makna, kecemasan sebagai kondisi dalam hidup dan kesadaran akan maut dan ketiadaan (Corey, 2013).

Ajeeng (2013) mengemukakan ciri-ciri eksistensial humanistik, yaitu: 1) Eksistensialisme merupakan pendekatan yang memusatkan perhatiannya tentang individu yang keberadaannya diakui oleh dunia; 2) Adanya dalil-dalil yang melandasi, pertama, setiap manusia adalah makhluk yang unik dalam mereaksikan dirinya tentang keberadaannya. kedua, 
manusia memiliki fungsi masing-masing berdasarkan unsur pribadi yang membentuk. ketiga, dalam sistem persepsinya menggunakan alat penginderaan stimulusrespon; 3) Melengkapi segala unsur psikologis yang ada pada diri tiap individu; 4) Sasarannya tentang bagaimana individu memahami perasaan, dan pengalamannya sebagai hasil keberadaan eksistensialnya; serta 5) Memiliki khas tentang tanggung jawab manusia, nilai-nilai yang dianut, makna terhadap hidup, kecemasan, keputusan, dan kematian.

Terdapat tiga langkah yang dilakukan dalam konseling eksistensial Corey (2013) antara lain: 1). Tahap pendahuluan, konseli mengklarifikasi asumsinya terhadap dunia dan pengalamannya yang dibantu oleh konselor. Konseli dituntun dalam mendefinisikan dan menanyakan tentang cara mereka memandang dan menjadikan eksistensi mereka bisa diterima; 2). Tahap pertengahan, konseli memaparkan lebih lanjut tentang nilai yang mereka anut dalam berperilaku dan menjalani hidup mereka; dan 3). Tahap pengakhiran, konseling berfokus pada menolong konseli untuk bisa melaksanakan apa yang telah mereka pelajari tentang diri mereka sendiri. Proses ini yang akan membuat remaja dapat menyadari baik dan buruknya suatu perilaku dan selanjutnya membentuk konsep diri yang positif, yang sesuai dengan aturan/ norma-norma yang ada dan pada akhirnya mampu menghargai dirinya.

Gambaran mengenai ciri gaya hidup hedonis diperkuat berdasarkan hasil studi pendahuluan di SMA Negeri 10 Makassar selama tiga hari pada tanggal 26, 27, dan 28 Januari 2017 yang menunjukkan bahwa ada siswa-siswa yang terindikasi melakukan perilaku hedonisme, yakni mereka menggunakan smartphone yang berlebihan dibandingkan teman-temannya, menunjukkan penampilan yang mencolok, teman lebih dijadikan sebagai "teman bermain" dibandingkan dengan teman belajar, memiliki akun media sosial seperti instagram dan facebook serta menganggap bahwa untuk terlihat eksis dan bisa melakukan update agar teman-teman bisa melihatnya maka mereka akan "nongkrong" di tempat-tempat terkini.

Eksistensial humanistik berpendapat bahwa terdapat dua jenis pribadi yaitu pribadi sehat dan pribadi bermasalah. Perilaku hedonisme merupakan salah satu jenis pribadi yang bermasalah. Pendekatan eksistensial berusaha mencari ambang batas ontologis dari sifat manusia, ini merupakan upaya konstektual yang bertujuan menghargai sepenuhnya sifat alami kita sebagai individu (DeRobertis, 2015, p. 331).

Penelitian sebelumnya mengenai konseling eksistensial humanistik berhasil meningkatkan kemampuan individu dalam bertindak, menerima kebebasan dan bertanggung jawab untuk berbagai tindakan yang dilakukannya. Penelitian Zyromski dkk. (2018) meneliti ACE (Adverse Childhood Experiences) melalui lensa eksistensial, dimana terapis memberikan beragam solusi yang bisa dilakukan oleh klien dan menawarkan kegiatan intervensinya. Intervensi terapeutik eksistensial termasuk mengajarkan klien tentang regulasi emosi dan membangun kemampuan klien tentang bagaimana menghadapi trauma yang dialami melalui pengalamannya tersebut. Landasan ACE ini dipengaruhi oleh pengalaman masa kanakkanak klien yang memicu berbagai reaksi eksistensial yang mengganggu kesehatan fisik, mental, dan perilaku. Artikel ini mengeksplorasi implikasi ACE untuk perkembangan anak-anak, remaja, dan orang dewasa.

Penelitian tentang ACE sangat kuat dalam literatur medis dan trauma tetapi tergolong baru dalam literatur konseling. Dalam sudut pandang eksistensial, program ACE ini membekali para konselor humanistik dengan strategi untuk mengatasi banyaknya masalah kesehatan medis, mental, dan perilaku negatif yang dihasilkan dari trauma kompleks ini.

Berdasarkan fenomena yang terjadi maka penulis tertarik untuk melakukan 
penelitian ini karena masalah ini sangat memengaruhi pemaknaan akan kehidupan remaja, pembentukan pribadi dan pendidikan remaja. Apabila tidak diberikan bantuan pada remaja akan membawa dampak yang negatif seperti yang disampaikan oleh Praja dan Damayanti (dalam Gemilang \& Christiana, 2016), yang menyebutkan terdapat tiga hal yang akan menjadi dampaknya yaitu dampak pada keinginan siswa dalam mencapai prestasi sekolah, motivasi belajar, dan memiliki pandangan yang materialis terhadap semua hal dan tidak memerdulikan hal sekitar dan yang menyangkut prestasi.

Layanan bimbingan konseling yang digunakan yaitu pendekatan konseling eksistensial humanistik, karena konseling eksistensial humanistik mengajak konseli untuk berusaha mencari makna dari pandangan eksistensi diri yang positif, tujuan, nilai, dan sasaran yang akan dicapai dengan mengubah sudut pandangnya tentang kejadian yang ada di lingkungan sehingga menumbuhkan kesadarannya untuk menggali potensi yang dimiliki. Adapun penelitian ini bertujuan untuk mengetahui gambaran perilaku hedonis siswa di SMA Negeri 10 Makassar serta mengetahui efektivitas penerapan pendekatan konseling eksistensial humanistik dalam mengurangi perilaku hedonis siswa tersebut.

\section{Metode Penelitian}

Penelitian ini menggunakan pendekatan kuantitatif dengan jenis penelitian eksperimen. Adapun jenis ekperimen yang digunakan adalah Pre-Experimental Design yang mengkaji tentang pengaruh penerapan pendekatan konseling eksistensial humanistik melalui layanan konseling kelompok untuk mengurangi perilaku hedonis siswa. Desain eksperimen yang digunakan adalah One-Group PretestPosttest Design.

Subjek dalam penelitian ini adalah siswa kelas XI SMA Negeri 10 Makassar.
Berdasarkan hasil pengamatan yang dilakukan oleh guru bimbingan dan konseling, terkait ciri-ciri perilaku hedonis yang paling sering nampak pada siswasiswi kelas XI tersebut, diperoleh sebanyak 7 siswa yang teridentifikasi berperilaku hedonis ditandai dengan perilaku siswa yang lebih senang bermain handphone saat guru sedang menjelaskan pelajaran di dalam kelas, membolos sekolah untuk nongkrong dengan teman-temannya, memakai aksesori agar terlihat keren, sering menyontek pekerjaan teman, waktu luang digunakan untuk bersenang-senang (tidak belajar, tidak mengerjakan tugas sekolah).

Teknik pengumpulan data penelitian ini menggunakan kuesioner dan obsevasi. Kuesioner diberikan kepada kelompok eksperimen untuk memperoleh gambaran tentang perilaku hedonis siswa pada kelompok eksperimen sebelum (pretest) maupun sesudah (posttest) diberikan konseling eksistensial humanistik melalui layanan konseling kelompok. Dari hasil uji validitas kuesioner ditemukan bahwa dari 45 item, yang tidak valid sebanyak 10 item disebabkan nilai $\mathrm{r}<.3$. Adapun hasil uji reliabilitas menunjukkan nilai koefisien alpha sebesar .809 sehingga kuesioner dapat dinilai reliabel.

Observasi digunakan untuk mencatat reaksi-reaksi dan perubahan selama mengikuti pelaksanaan konseling eksistensial humanistik melalui konseling kelompok dengan pengamatan secara langsung terhadap subjek penelitian. Adapun aspek-aspek yang diobservasi adalah aktivitas, minat, dan opini. Cara penggunaannya dengan cara memberi tanda cek $(\sqrt{ })$ pada setiap aspek yang muncul. Kriteria penentuan hasil observasi dibuat berdasarkan hasil analisis persentase individual dan analisis kelompok, yaitu nilai tertinggi $100 \%$ dan angka terendah $0 \%$ sebagaimana disajikan pada tabel 1 . 
Tabel 1

Kriteria Penentuan Hasil Observasi

\begin{tabular}{rc}
\hline Persentase & Kriteria \\
\hline $80 \%-100 \%$ & Sangat tinggi \\
$60 \%-79 \%$ & Tinggi \\
$40 \%-59 \%$ & Sedang \\
$20 \%-39 \%$ & Rendah \\
$0 \%-19 \%$ & Sangat rendah \\
\hline
\end{tabular}

Guna memperoleh gambaran umum tentang perilaku hedonisme siswa SMA Negeri 10 Makassar sebelum dan sesudah perlakuan konseling eksistensial humanistik melalui layanan konseling kelompok, untuk keperluan tersebut maka dilakukan perhitungan interval untuk memperoleh 4 kategori sebagaimana disajikan pada tabel 2. Teknik analisis inferensial nonparametrik yang digunakan adalah Wilcoxon Signed Ranks Test (Z) dari skor pretest dan posttest (Tiro, 2014).

Tabel 2.

Kategorisasi Tingkat Perilaku Hedonis

\begin{tabular}{cc}
\hline Interval & Kategori \\
\hline $116-142$ & Sangat Tinggi \\
$89-115$ & Tinggi \\
$62-88$ & Rendah \\
$35-61$ & Sangat Rendah \\
\hline
\end{tabular}

\section{Hasil Penelitian dan Pembahasan}

Berikut ini disajikan data perilaku hedonis siswa sebelum dan sesudah diberi perlakuan dengan menggunakan pendekatan konseling eksistensial humanistik di SMA Negeri 10 Makassar.

Tabel 3 menunjukkan tingkat perilaku hedonis siswa sebelum diberi perlakuan (pretest), yaitu 2 responden $(28.57 \%)$ yang berada pada kategori sangat tinggi, 4 responden $(57.14 \%)$ berada pada kategori tinggi, dan 1 responden (14.28\%) pada kategori rendah, sedangkan pada kategori sangat rendah tidak ada responden. Sesuai dengan nilai rata-rata skor yang diperoleh sebesar 102.57 yang nilai rata-rata tersebut dibulatkan menjadi 103 dan berada pada interval 89-115 yang berarti tinggi (tabel 4). Hal ini berarti bahwa tingkat perilaku hedonis siswa di SMA Negeri 10 Makassar berada dalam kategori tinggi.

Tabel 3

Tingkat Perilaku Hedonis pada Pretest dan Posttest

\begin{tabular}{lcccc}
\hline \multirow{2}{*}{ Kategori } & \multicolumn{2}{c}{ Pretest } & \multicolumn{2}{c}{ Posttest } \\
\cline { 2 - 5 } & $\mathrm{f}$ & $\%$ & $\mathrm{f}$ & $\%$ \\
\hline Sangat Tinggi & 2 & $28.6 \%$ & 0 & $0 \%$ \\
Tinggi & 4 & $57.1 \%$ & 2 & $28.6 \%$ \\
Rendah & 1 & $14.3 \%$ & 3 & $42.9 \%$ \\
Sangat Rendah & 0 & $0 \%$ & 2 & $28.5 \%$ \\
Total & 7 & 100 & 7 & 100 \\
\hline
\end{tabular}

Setelah diberi perlakuan pendekatan konseling eksistensial humanistik sebanyak 7 kali pertemuan, tingkat perilaku hedonis siswa SMA Negeri 10 Makassar mengalami penurunan. Hal ini dapat dilihat dari tingkat perilaku hedonis siswa tidak ada responden yang berada pada kategori sangat tinggi, kemudian pada kategori tinggi terdapat 2 reponden $(28.57 \%)$, pada kategori rendah terdapat 3 responden $(42.85 \%)$, dan terdapat 2 responden (28.57\%) pada kategori sangat rendah. Selanjutnya sesuai dengan nilai rata-rata skor yang diperoleh sebesar 74 berada pada interval 62-88 yang berarti rendah (tabel 4), hal ini menunjukkan bahwa tingkat perilaku hedonis siswa setelah diberikan perlakuan pendekatan konseling eksistensial humanistik berada pada kategori rendah.

Tabel 4

Kecenderungan Umum Penelitian Berdasarkan Pedoman Interpretasi Perilaku Hedonis Siswa

\begin{tabular}{lccc}
\hline \multicolumn{1}{c}{ Jenis Data } & Mean & Interval & Klasifikasi \\
\hline Pretest & 102.57 & $89-115$ & Tinggi \\
Posttest & 74 & $62-88$ & Rendah \\
\hline
\end{tabular}

Pada tabel 5 disajikan data hasil analisis observasi berdasarkan tiap-tiap aspek selama pelaksanaan perlakuan pendekatan konseling eksistensial humanistik di SMA Negeri 10 Makassar. 
Tabel 5

Hasil Persentase Analisis Data Observasi setiap Aspek

\begin{tabular}{lccccccc}
\hline & \multicolumn{7}{c}{ Pertemuan } \\
\cline { 2 - 8 } Aspek & I & II & III & IV & V & VI & VII \\
\hline 1 & 28.5 & 42.8 & 57.1 & 71.4 & 85.7 & 85.7 & 100 \\
2 & 57.1 & 85.7 & 85.7 & 85.7 & 85.7 & 100 & 100 \\
3 & 42.8 & 71.4 & 71.4 & 85.7 & 100 & 100 & 100 \\
4 & 57.1 & 57.1 & 71.4 & 85.7 & 85.7 & 100 & 100 \\
5 & 57.1 & 71.4 & 71.4 & 71.4 & 85.7 & 85.7 & 100 \\
6 & 42.8 & 57.1 & 71.4 & 85.7 & 100 & 100 & 100 \\
\hline
\end{tabular}

Tabel 5 menunjukkan data hasil analisis pada setiap aspek yang diobservasi selama pelaksanaan pendekatan konseling eksistensial humanistik. Aspek pertama yaitu berkurangnya keinginan terhadap halhal yang bersifat fisik, pada pertemuan pertama hanya ditunjukkan oleh 2 responden $(28.5 \%)$ hal ini disebabkan siswa masih kurang memahami hal yang dibahas. Pada pertemuan kedua mengalami peningkatan menjadi 3 responden $(42.8 \%)$, pertemuan ketiga menjadi 4 responden (57.1\%), pertemuan keempat sebanyak 5 responden $(71.4 \%)$, pertemuan kelima dan keenam juga kembali meningkat, yang mana siswa telah memiliki niat untuk mengurangi keinginannya terhadap hal yang bersifat fisik yaitu pada 6 responden (85.7\%), adapun pada pertemuan ketujuh seluruh responden (100\%) mengalami peningkatan, hal ini dapat dilihat dari peningkatan persentase siswa yang mulai mencoba mengurangi keinginan-keinginan terhadap hal yang bersifat fisik, terlihat dari antusiasme siswa pada saat memaparkan pendapat mengenai keinginannya.

Aspek kedua yaitu mampu menabung, menyimpan/ menyisihkan uang untuk memenuhi kebutuhan dan bukan keinginannya, pada pertemuan pertama ditunjukkan oleh 4 responden $(57.1 \%)$, dan mengalami peningkatan menjadi 6 responden $(85.7 \%)$ yang berlangsung stabil pada pertemuan kedua, ketiga, keempat dan kelima. Adapun pada pertemuan keenam dan ketujuh mengalami peningkatan yakni ditunjukkan oleh semua responden (100\%), hal ini terlihat dari sikap antusias siswa dalam memaparkan rencana mereka berkaitan dengan perencanaan dalam hal menyisihkan uang untuk memenuhi kebutuhan bukan keinginannya.

Aspek ketiga yaitu menyadari bahwa segala kebutuhan dalam hidup harus lebih direalisasikan dibandingkan keinginankeinginan spontan yang tidak penting, pada pertemuan pertama ditunjukkan oleh 3 responden $(42.8 \%)$, hal ini disebabkan siswa masih belum mampu menyadari bahwa kebutuhan harus diutamakan dibandingkan keinginan. Pertemuan kedua dan ketiga mengalami peningkatan dengan persentase yang sama yakni 5 responden (71.4\%), pertemuan keempat menjadi 6 responden $(85.7 \%)$, adapun pertemuan kelima, keenam, dan ketujuh mengalami peningkatan pada seluruh responden (100\%). Pada tahap ini siswa telah menyadari bahwa segala kebutuhan dalam hidup harus lebih direalisasikan dibandingkan keinginan-keinginan spontan yang sifatnya tidak penting.

Aspek keempat yaitu bertanggung jawab, pada pertemuan pertama dan kedua memiliki persentase yang sama yakni terdapat pada 4 responden $(57.1 \%)$ hal ini disebabkan siswa masih belum mampu memandang bahwa hidup harus dilalui dengan usaha dan tanggung jawab agar mencapai tujuan. Pertemuan ketiga mengalami peningkatan menjadi 5 responden $(71.4 \%)$, pertemuan keempat dan kelima juga mengalami peningkatan menjadi 6 responden $(85.7 \%)$, serta pertemuan keenam dan ketujuh mengalami peningkatan sepenuhnya $(100 \%)$ karena siswa telah menyadari bahwa dirinya harus bertanggung jawab terhadap kehidupannya.

Aspek kelima yaitu tanggapan positif/ optimis, pada pertemuan pertama terdapat pada 4 responden $(42.8 \%)$, pertemuan kedua, ketiga dan keempat mengalami peningkatan dengan persentase sama yakni pada 5 responden $(57.1 \%)$, pertemuan kelima dan keenam juga mengalami peningkatan dengan persentase yang sama pula yakni 6 responden (85.7\%), serta 
pertemuan ketujuh mengalami peningkatan pada seluruh responden (100\%).

Aspek terakhir yaitu berkurangnya motif dan keinginan untuk bersenangsenang, pada pertemuan pertama terdapat pada 3 responden $(42.8 \%)$ hal ini disebabkan siswa masih kurang mampu mengendalikan keinginannya dalam bersenang-senang. Pertemuan kedua mengalami peningkatan menjadi 4 responden $(57.1 \%)$, pertemuan ketiga menjadi 5 responden $(71.4 \%)$, pertemuan keempat menjadi 6 responden $(85.7 \%)$, adapun pertemuan kelima, keenam, dan ketujuh mengalami peningkatan sepenuhnya yang ditunjukkan oleh 7 responden $(100 \%)$. Pada tahap ini siswa telah mampu mengurangi motif, keinginankeinginan terhadap barang-barang branded dan keinginan untuk bersenang-senang.

Gambaran tingkat keaktifan siswa dalam pelaksanaan pendekatan konseling eksistensial humanistik di SMA Negeri 10 Makassar disajikan pada tabel 6. Data menunjukkan bahwa partisipasi siswa dalam proses konseling eksistensial humanistik berjalan dengan sangat baik karena mengalami peningkatan dalam hal partisipasi, reaksi-reaksi, serta perilaku siswa ke arah yang lebih baik.

Tabel 6

Data Partisipasi Siswa selama Pelaksanaan Konseling Eksistensial Humanistik

\begin{tabular}{lccccccc}
\hline & \multicolumn{1}{c}{ Pertemuan } \\
\cline { 2 - 8 } \multicolumn{1}{c}{ Kriteria } & I & II & III & IV & V & VI & VII \\
\hline Sangat tinggi & 0 & 1 & 2 & 5 & 5 & 7 & 7 \\
Tinggi & 2 & 4 & 5 & 2 & 2 & 0 & 0 \\
Sedang & 2 & 2 & 0 & 0 & 0 & 0 & 0 \\
Rendah & 3 & 0 & 0 & 0 & 0 & 0 & 0 \\
Sangat rendah & 0 & 0 & 0 & 0 & 0 & 0 & 0 \\
Jumlah & $\mathbf{7}$ & $\mathbf{7}$ & $\mathbf{7}$ & $\mathbf{7}$ & $\mathbf{7}$ & $\mathbf{7}$ & $\mathbf{7}$ \\
\hline
\end{tabular}

Tabel 7

Hasil Uji Wilcoxon (Z)

\begin{tabular}{cccccc}
\hline \multicolumn{2}{c}{ Mean } & \multicolumn{2}{c}{ SD } & Asymp & Sig. \\
Pre- & Post- & Pre- & Post- & sig<a & $2-$ \\
Test & test & test & test & $Z$ & tailed \\
\hline 102.57 & 74 & 13.21 & 13.03 & $-2.366^{\mathrm{a}}$ & .008 \\
\hline
\end{tabular}

Berdasarkan hasil perhitungan yang disajikan pada tabel 7, diperoleh nilai statistik uji $\mathrm{Z}$ sebesar -2.366 dan nilai signifikansi $.008<.05$ sehingga $\mathrm{H}_{0}$ ditolak. Dapat dilihat bahwa nilai rata-rata sebelum diberikan perlakuan lebih tinggi dibandingkan setelah diberikan perlakuan, dimana sebelum diberikan perlakuan hasil rata-rata nilai pretest sebesar 102.57 dan setelah diberikan perlakuan hasil rata-rata nilai posttest berkurang menjadi 74 sehingga terlihat adanya perubahan yang dialami siswa. Adanya perbedaan signifikan nilai rata-rata sebelum dan setelah diberi perlakuan berupa pendekatan konseling eksistensial humanistik, maka dapat dikatakan bahwa pelaksanaan pendekatan konseling eksistensial humanistik dapat mengurangi perilaku hedonis siswa di SMA Negeri 10 Makassar.

Fakta yang ada pada siswa SMA Negeri 10 Makassar khususnya kelas XI MIA 7 dan XI IIS 3 yang menjadi sampel dalam penelitian ini memiliki tingkat perilaku hedonis berada pada kategori tinggi pada saat diberikan pretest. Berbagai indikasi yang menunjukkan bahwa siswa berperilaku hedonis di sekolah tersebut, terlihat pada beberapa siswa yang selalu berperilaku sesuai keinginan sendiri seperti berpenampilan yang berlebihan, menggunakan aksesori tambahan, selalu ingin menjadi pusat perhatian, bermain gadget sepanjang waktu untuk sosial media, memiliki geng, tidak mengerjakan pekerjaan rumah (PR) serta lebih memilih bermain, menghabiskan waktu untuk bersenang-senang dibandingkan mengerjakan tugas akademiknya, tidak memerhatikan guru saat menjelaskan, serta tidak mengikuti aturan yang ada di lingkungan sekitarnya.

Anwar (2011, p. 162-163) mengemukakan bahwa pribadi yang tidak sehat menurut eksistensial humansitik yaitu orang-orang yang tidak mampu memfungsikan kesadaran akan keberadaannya dengan baik sehingga potensi yang dimiliki tidak difungsikan dengan baik, seperti tidak produktif, tidak dipercaya, 
memahami diri dengan arti yang salah, dan kurang memiliki teman.

Seperti halnya perilaku hedonis yang dilakukan siswa disebabkan oleh adanya kekeliruan dalam memandang serta memaknai arti kehidupan eksistensinya, dimana kekeliruan itu karena dia melihat eksistensi itu melekat pada apa yang ditunjukkan/ ditampilkan oleh individu meskipun itu tidak sesuai dengan diri dan nilai yang ada di masyarakat. Siswa hedonis tidak lagi memerhatikan nilai-nilai yang ada dan cenderung melakukan apa yang disenanginya sehingga lingkungan melihat keberadaan dirinya berdasarkan apa yang disenangi, yang membuat siswa tersebut tidak dapat memfungsikan dimensi dasar yang dimiliki manusia. Perilaku hedonis yang dilakukan termasuk dalam kategori pribadi yang tidak sehat.

Hasil penelitian menunjukkan bahwa tingkat perilaku hedonis siswa pada saat pretest berada pada kategori tinggi dengan mean sebesar 102.57 dan berkurang pada saat posttest dengan mean sebesar 74 tergolong kategori rendah (lihat table 5). Setelah diberikan perlakuan berupa pendekatan konseling eksistensial humanistik terlihat adanya perubahan atau tingkat perilaku hedonis siswa setelah diberikan perlakuan pendekatan konseling eksistensial humanistik mengalami penurunan.

Pendekatan eksistensial humanistik bertujuan untuk bagaimana individu dapat memahami dirinya secara otentik dan sadar akan eksistensi dan segala pengalamannya. Adapun ketiga tahap (Corey, 2007) yang diterapkan dalam konseling kelompok yaitu: 1) Tahap pendahuluan, merupakan kegiatan konseling kelompok yang bertujuan untuk mengetahui klarifikasi asumsi siswa dan definisi cara memandang serta menjadikan eksistensinya sehingga bisa diterima. Mengetahui semua pengalaman siswa tentang eksistensi yang dilakukan ataupun yang telah diamatinya. Setiap siswa memaparkan semua asumsi, pandangan, pengamatan dan pengalaman mereka terhadap eksistensi yang mereka pahami. 2) Tahap pertengahan, merupakan kegiatan konseling kelompok melalui dinamika kelompok untuk mengetahui gagasan siswa tentang proses pemberian nilai internal (pengalaman dan pengamatan, motif, persepsi), sikap serta perilaku yang mereka anggap pantas. Dari tanggapan dan pemaparan yang dikemukakan oleh para siswa dapat disimpulkan melalui catatan anekdot mengenai berkurangnya kebutuhan prestise yang akan membentuk konsep diri menjadi lebih baik/ konsep diri apa adanya, dalam mengeksplorasi segala nilai dan sikap mereka yang memunculkan pemahaman baru. 3) Tahap pengakhiran, merupakan kegiatan konseling kelompok yang menekankan pada cara untuk menemukan kebermaknaan eksistensinya dengan mengembangkan potensi yang dimiliki. Siswa saling bertukar pendapat tentang pengalaman mereka dan nilai kehidupan mereka sehingga muncul nilai yang baru dari apa yang telah dilalui kemudian menemukan kebermaknaan hidup serta mengembangkan segala potensi yang dimilikinya ke arah yang lebih positif.

\section{Simpulan}

Remaja yang cenderung melakukan perilaku hedonis ditandai dengan ciri-ciri yaitu selalu update terhadap perkembangan trend terkini, cemas bila tidak mengikuti trend karena berfikir akan dijauhi oleh teman sebaya dan memiliki gengsi yang tinggi. Setelah diberikan perlakuan berupa pendekatan konseling eksistensial humanistik terlihat adanya perubahan yang terjadi atau tingkat perilaku hedonis siswa di SMA Negeri 10 Makassar setelah diberikan perlakuan pendekatan konseling eksistensial humanistik mengalami penurunan.

Dalam pelaksanaan pendekatan konseling eksistensial humanistik terdiri dari tiga tahap yaitu tahap pendahuluan dimana pada tahap ini merupakan tahap awal untuk mengidentifikasi asumsi, pengalaman dan cara mereka memandang dan menjadikan 
eksistensi mereka dapat diterima. Tahap pertengahan yang merupakan tahap eksplorasi diri siswa untuk meneliti lebih dalam serta melihat dan mengetahui sistem nilai otoritas mereka terhadap perilaku hedonisnya sehingga memunculkan berkurangnya kebutuhan akan prestise tersebut. Proses ini membuat siswa dapat menyadari baik dan buruknya suatu perilaku serta menemukan pemahaman baru dari nilai internal dan sikap mereka. Tahap akhir merupakan tahap aktualisasi dalam mengaplikasikan nilai dari hasil internalisasi sehingga siswa dapat mempunyai pandangan yang positif terhadap eksistensi, percaya diri, serta membentuk konsep diri yang positif sehingga dapat menerima diri apa adanya. Proses tersebut dapat membantu siswa dalam mengurangi perilaku hedonis dengan mengubah pandangan eksistensi yang dipahami oleh mereka. Dengan demikian penerapan pendekatan konseling eksistensial humanistik terbukti efektif dalam mengurangi perilaku hedonis siswa di SMA Negeri 10 Makassar.

\section{Daftar Pustaka}

Ajeeng, N. (2013). Terapi eksistensial humanistik. Diakses pada tanggal 17 Maret 2017 melalui https://nurainiajeeng.wordpress.com/20 13/03/24/terapi-eksistensialhumanistik/.

Anwar, M. F. (2011). Terapi eksistensial humanistik dalam konseling Islam. Jurnal Holistik, 12(01), 157-180.

Corey, G. (2013). Teori dan praktek konseling dan psikoterapi (edisi ketujuh). Bandung: PT Refika Aditama.

Craik, F. I. M., Rose, N. S., \& Gopie, N. (2015). Recognition without awareness: Encoding and retrieval factors. Journal of Experimental Psychology: Learning, Memory, and Cognition, 41(5), 1271-1281. doi.org/10.1037/xlm0000137
DeRobertis, M. E. (2015). Philosophicalanthropological considerations for an existential-humanistic ecopsychology. The Humanistic Psychologist. Brookdale Community College and Rutgers University-Newark. doi: 10.1080/08873267.2014.961637

Felder, A. J., Aten, H. M., Neudeck, J. A., Shiomi-Chen, J., \& Robbins, B. D. (2014). Mindfulness at the heart of existential phenomenology and humanistic psychology: A century of contemplation and elaboration. Humanistic Psychologist, 42(1), 6-23. doi.org/10.1080/08873267.2012.75388 6

Gemilang, R., \& Christiana, E. (2016). Pengembangan booklet sebagai media layanan informasi untuk pemahaman gaya hidup hedonisme siswa kelas XI di SMAN 3 Sidoarjo. Jurnal $B K$ Unesa, 6(3).

Hadi, S. (2016). Statistik, edisi revisi. Cetakan ketiga. Yogyakarta: Pustaka Pelajar.

Jones, R. N. (2011). Teori dan praktik konseling dan terapi. Edisi keempat. Yogyakarta: Pustaka Pelajar.

Lubis, N. L. (2011). Memahami dasardasar konseling dalam teori dan praktek. Jakarta: Kencana

May, R., \& Yalom, I. D. (2005). "Existential Psychotherapy", dalam R. J. Corsini dan D. Wedding (Eds.), Current psychotherapies (7th ed., instr. ed.). Belmont, CA, US: Thomson Brooks/Cole Publishing Co.

Nadzir, M., \& Ingarianti, T. M. (2015). Psychological meaning of money dengan gaya hidup hedonis remaja di kota Malang. Psychology Forum UMM, ISBN: 978-979-796-324-8.

Nitadyah, P. (2015). Hedonisme. Diakses pada tanggal 19 Maret 2017 dari https://purplenitadyah.wordpress.com/2 012/05/05/hedonisme/

Primayanti, Hendri, Madriantari, \& Dantes, N. (2014). Penerapan konseling eksistensialis humanistik melalui 
konseling kelompok untuk meningkatkan tanggung jawab belajar siswa kelas VIII SMP negeri 3 Singaraja. e-journal Undiksa Jurusan Bimbingan Konseling, 2(1). Universitas Pendidikan Ganesha.

Pontania, A. R. (2016). Hubungan antara konsep diri dengan gaya hidup hedonis pada siswa SMA negeri 4 Surakarta. (Skripsi tidak diterbitkan). Universitas Muhammadiyah Surakarta, Fakultas Psikologi.

Rochem. (2011). Teori belajar humanistik. Diakses pada 10 Maret 2017 dari https://rochem.wordpress.com/2011/12/ 16/teori-belajar-humanistik/

Sabrina, R. (2016). Konseling eksistensial untuk meningkatkan kebermaknaan hidup pada penderita skizofrenia: Studi kasus. Seminar ASEAN 2nd Psychology \& Humanity, Psychology Forum UMM. Universitas Muhammadiyah Malang.

Sarlina, R. D. (2016). Hubungan antara konsep diri dengan kecenderungan gaya hidup hedonis pada remaja klub mobil violet auto female di kota Purwokerto. (Tesis tidak diterbitkan). Universitas Muhammadiyah Purwokerto, Fakultas Psikologi.

Simon, S. (2017). Pengaruh teknik bibliokonseling terhadap pembentukan konsep diri siswa di SMPN 1 Bua Porang kab Luwu. (Tesis tidak diterbitkan) Universitas Negeri Makassar, Program Pascasarjana.

Sugiyono. (2015). Metode penelitian pendidikan: Pendekatan kuantitatif, kualitatif, dan $R \& D$. Bandung: Alfabeta.

Tiro. (2014). Penelitian eksperimen. Makassar: Andira Publisher.

Trimartati, N. (2014). Studi kasus tentang gaya hidup hedonisme mahasiswa bimbingan dan konseling Universitas Ahmad Dahlan. Psikopedagogia, 3(1), 20-28.

Wijaya, R. S. (2014). Model konseling kelompok eksistensial humanistik untuk mengurangi kecemasan siswa menentukan arah peminatan SMA negeri Semarang. Jurnal Bimbingan Konseling, 3(2).

Wolfe, B. (2016). Existential-humanistic therapy and psychotherapy integration: A commentary. American Psychological Association, 26(1), 5660. doi.org/10.1037/int0000023

Yulianto. (2015). Guided imagery: Konsep konseling kreatif untuk penanganan post traumatic stress disorder (PTSD). Jurnal Fokus Konseling, 1(1), 70-81.

Zyromski, B., Dollarhide, C. T., Aras, Y., Geiger, S., Oehrtman, J. P., \& Clarke, H. (2018). Beyond complex trauma: An existential view of adverse childhood experiences. Journal of Humanistic Counseling, 57(3), 156172. doi.org/10.1002/johc.12080 
Psympathic, Jurnal Ilmiah Psikologi Juni 2019, Vol. 6, No. 1, Hal. : 41-52 